\title{
Government scheme encourages more collaborative research
}

\section{London}

THE British government last week officially launched its much-vaunted LINK initiative, designed to encourage collaborative scientific research between the private and public sectors and to accelerate the commercial exploitation of government-funded research. No new money is being made available for the initiative, which was first announced more than a year ago, and public funding for LINK programmes will be drawn from existing research budgets of government departments and research councils. The government will contribute up to 50 per cent of the costs of a LINK project. Whether LINK will succeed in tempting industry to increase its investment in research remains to be seen.

Research programmes will be in 'strategic' areas of science, for which industrial applications are expected to be attainable with $8-10$ years. Proposals for programmes will require approval by a LINK steering group, comprising representatives from industry, the government and academic science. Programmes will usually run for between three and five years, and will be administered by the government department with the greatest financial stake. Thus public support will be withdrawn well before commercial exploitation is in sight, in line with the government's recent declaration that it will no longer fund 'near market' researches.

Five initial programmes have been approved. So far they involve only the Department of Trade and Industry and the Science and Engineering Research Council (SERC) but the intention is that other departments with research interests (notably the Ministry of Defence) will eventually subscribe to LINK. Just over $£ 40$ million of government funds is available for the five programmes but will only be spent if matching funds are forthcoming from industry. The eventual total contribution of the government is expected to amount to $£ 210$ million over five years

In general, the initiative has been welcomed by the academic and industrial research community, although there is concern that LINK's long gestation period (it was first announced by Prime Minister Margaret Thatcher in October 1986) suggests underlying difficulties that may not yet be completely resolved.

On the thorny subject of intellectual property rights (IPR), believed to have been one of the main sticking points during early discussions, the government says: "The IPR regime for each LINK programme will be agreed before the programme begins and will be that which the sponsors and participants consider most suitable for the programme in question." IPR will generally go to the industrial partners "with suitable recompense negotiated for the science base partner(s)" The hope is that disputes over IPR will seldom arise, given that the research will usually be pre-competitive.

A significant concession won by the academic participants in LINK is that money allocated by the University Grants Committee to cover an institution's research overheads will not be considered as part of the government's 50 per cent contribution, and research overheads on a LINK project will be met by the funding agency.

The five approved programmes cover molecular electronics, advanced semiconductor materials, industrial measurement systems, eukaryotic genetic engineering and nanotechnology. No contracts have yet been drawn up, and most prospective partners have only "expressed interest". Simon Hadlington - The first LINK contract is likely to be in the Eukaryotic Genetic Engineering Programme - the smallest of the five programmes. The University of Oxford is close to completing the contract that will establish a Centre for Eukaryotic Molecular Genetics in its biochemistry department with support from British Bio-technology Ltd and Glaxo. A total of $£ 750,000$ over four years, half from the two companies and half from the Department of Trade and Industry and SERC, will flow into the centre, where it will be spent on research into the synthesis and secretion of proteins from human cells.

Other projects within the Eukaryotic Genetic Engineering Programme are less advanced, although one centred on the University of Leicester is a strong candidate. But if the $£ 2.3$ million available from government sources is to be taken up, further industrial interest will be necessary. SERC is to hold a meeting in March to foster such interest.

Peter Newmark

\section{New US space policy opens up the future to private industry}

\section{Washington \& Munich}

PRESIDENT Ronald Reagan has signed a new comprehensive national space policy that will help direct the future of United States activities in space. The new policy is the result of an 18-month review of previous space efforts, and covers issues of national security, commercial development of space, and research and exploration.

Since 1983, the Reagan administration has been pushing to involve private industry in space services that have traditionally been in the domain of NASA (National Aeronautics and Space Administration). Launch services were the first to be considered, although there was little incentive for private rocket manufacturers to compete with NASA's space shuttle until the Challenger accident put all further shuttle launches on hold (see Nature 331, 380; 1988).

Now, private involvement will extend to other areas, including a mini-space station called the Industrial Space Facility (ISF), being developed by Space Industries, Inc. of Houston, Texas. NASA has been concerned that a national commitment to ISF will dilute support for the $\$ 14,600$-million space station it is developing. ISF costs are expected to run about 5 per cent of that amount

But according to a high administration official, ISF will complement NASA's space station, not compete with it. The Reagan administration will ask Congress for $\$ 6,100$ million over the next 3 years for the space station, but only one sixth of that total will be requested for the 1989 budget.

Also included in the new policy is a commitment to NASA's Pathfinder project, to develop advanced technology for the exploitation of space. The administration will request $\$ 100$ million in its 1989 budget for this initiative. According to the administration source, the White House feels developing sophisticated technology to send astronauts to the Moon only to abandon it when that task was accomplished was a mistake. The new policy will attempt to provide a more coherent, longrange approach to space that will start in earth orbit, but move beyond as the technology is developed and the need arises. There are no specific goals for renewed human exploration of the Moon or a mission to Mars, but these are certainly possibilites.

The White House now perceives a clear need for a heavy lift vehicle capable of launching payloads weighing between 50 and 100 metric tonnes. This vehicle will go into service in the second half of the next decade, according to current plans.

The president was expected to announce the new space policy in his State of the Union address to Congress on 25 January. However, differences of opinion within the administration over the federal commitment to ISF have prompted an indefinite delay in any formal announcement.

Steven Dickman \& Joseph Palca 